\title{
CEP55 Gene
}

National Cancer Institute

\section{Source}

National Cancer Institute. CEP55 Gene. NCI Thesaurus. Code C104119.

This gene is involved in mitotic exit and cytokinesis. 